\title{
Respecting Human Rights While Countering Terrorism
}

\section{An Impression}

\author{
Piet de Klerk \\ President of the Supervisory Board of the Netherlands Helsinki Committee; \\ former Netherlands Ambassador-at-large and Special Counterterrorism \\ Envoy; former Dutch Ambassador for Human Rights \\ pietdeklerk2017@gmail.com
}

\begin{abstract}
This is an article by a practitioner who has worked on two sides of the divide between countering terrorism and protecting human rights, both as Netherlands Human Rights Ambassador and later as the Dutch Special Counterterrorism Envoy. What was most striking in looking at these two periods that were roughly a decade apart, was how different the issues and perspectives at the junction of countering terrorism and respecting human rights were. These can be attributed to three factors: 1 ) that in the first period the shock of $9 / 11$ was still new and the US was in overdrive; 2) the differences between al-Qaeda and the Islamic State; and 3) revolutionary technological changes that have an impact on human rights and on the way a terrorist organization can function these days.
\end{abstract}

\section{Keywords}

human rights - counterterrorism - (role of) the Netherlands - Guantanamo - 9/11 Global Counterterrorism Forum (GCTF) 
The description of the fields of promoting and protecting human rights on the one hand and countering terrorism on the other, and occasionally my own contributions to the international debates in these fields, pertain to two periods in my career at the Netherlands Foreign Ministry. Over the years, the Ministry has created a varying number of special envoys for themes that were priorities in Dutch foreign policy. In 2003, I was asked to step into the shoes of the Human Rights Ambassador, a position that had been created a few years before. I did that until 2007. After a period at the Netherlands Permanent Mission in New York, where I was occasionally active both in the fields of human rights and of counterterrorism - a stint as Dutch ambassador in Jordan, which coincided with the Arab spring and the rise of Jabhat al-Nusra in Syria, and leading the Sherpa team for the Nuclear Security Summit in The Hague in early 2014 - I was asked to become the Special Counterterrorism Envoy in June 2014. This was a position in the Dutch Foreign Ministry that was newly created, both in light of the urgency of the terrorist threat itself and of the Netherlands' wish to play an active role in the various international counterterrorist fora.

The threat was clear enough. In early 2014 Islamic State of Iraq and the Levant (ISIL) also known as the Islamic State of Iraq and Syria (ISIS) ${ }^{2}$ had taken full control of Raqqa, taking over from Jabhat al-Nusra, which had pushed out the representatives of the Al-Assad regime in that area the year before. And in June 2014, with lightning speed, ISIL had taken over the Niniveh province in Iraq and in particular its capital Mosul. On June 29th IsIL leader Abu Bakr alBaghdadi announced in Mosul the creation of the Islamic State (IS), combining Syrian and Iraqi territory as part of a worldwide caliphate. By that time 100 Dutch citizens (or residents) had gone to Syria or Iraq. ${ }^{3}$ The Netherlands' ambition to play a leading role in the fight against terrorism was realized in the course of my first year. ${ }^{4}$ Based on an earlier initiative ${ }^{5}$ together with Morocco, a working group on foreign terrorist fighters was established within the Global

1 This article is based on a presentation for the Editorial Board of Security and Human Rights on 7 October 2019.

2 After June 2014 called Islamic State or Da'esh, as the group was called by colleagues from Muslim-majority countries who didn't like the appropriation of the word "Islamic".

3 According to a letter to Parliament of 30 June 2014, by then 130 "Foreign Terrorist Fighters" had travelled to IS territory, of which 30 had returned.

4 This achievement was largely the result of efforts that had been underway for over a year.

5 The initiative was prepared by my colleagues in the Division for countering terrorist and transnational threats, headed by Lars Tummers and before him Frank van Beuningen. The starting point for the FTF working group was the The Hague - Marrakech Memorandum on Good Practices for a More Effective Response to the FTF Phenomenon, adopted in September 2014 . 
Counterterrorism Forum (GCTF) under Dutch/Moroccan chairmanship. In September 2014, the Netherlands was informally asked whether we were willing to take over the chairmanship of the GCTF as a whole. The answer was yes, which a year later was formalized, again together with co-chair Morocco, ${ }^{6}$ taking over from the original co-chairs, the United States and Turkey. ${ }^{7}$ In March 2015 the Netherlands, in this case together with Turkey, also assumed the cochairmanship of the newly created Foreign Terrorist Fighters (FTF) Working Group in the context of the Global Coalition against ISIL, which had been created late 2014. Of course, the Netherlands contributed in other ways to the work of the Coalition, mainly military, for example by training Iraqi forces and having a number of F-16's in Jordan for a few years, which played an important role in the fight against IS.

Not only did I start in a rather tumultuous period, I stepped down in October 2017 in a period with equally momentous changes. In June 2017, Iraqi government forces supported by the Global Coalition had retaken Mosul after heavy fighting and a few months later Kurdish forces, also supported by the Coalition, were able to liberate Raqqa.

I remember watching the TV programme College Tour in the spring of 2016 in which Utrecht historian Beatrice de Graaf pointed to the four waves of modern terrorism as described by David Rapoport in 2004, analysing the rising and ebbing away of earlier terrorist movements and predicting that this fourth wave would disappear as well. It was difficult to imagine then, but in retrospect it is striking how quickly the storm has subsided. Of course, the problem has not been solved and in some parts of the world it may be increasing again, but it is notable how quickly terrorism has disappeared from the headlines. Much of that is related to the disappearance of a state-like entity on parts of Iraqi and Syrian territory, which effectively came to an end when Mosul and later Raqqa fell.

Terrorism

What sort of violence should we label as terrorism? Drugs related violent crime in which innocent people die? Shooting people in a tram in Utrecht?

6 In 2016 and 2017 I co-chaired together with the man who is now the Moroccan Foreign Minister, Nasser Bourita.

7 The GCTF had been launched in 2011 by Hillary Clinton, the US Secretary of State and her Turkish counterpart Ahmet Davotoğlu. It has 30 members, about half of them states which have a Muslim majority. For reasons of continuity Morocco rotated in a year after the Netherlands took over from the US. In September 2019 the Netherlands handed over the GCTF co-chairmanship to Canada. 
The Netherlands Coordinator for Security and Counterterrorism defines terrorism as committing ideology-driven violent crimes, be it murder or causing material damage - with a view to destabilising society, influencing policies and /or inflicting terror among people. So: an ideological motive. As a consequence, the purely financial motives of the drugs king falls outside the terrorism scope. The tram shooter can be considered terrorism, only if it can be proven that his motives were of a terrorist nature instead of random fury. ${ }^{8}$ Nonetheless, these remain difficult definitional issues, which have not been resolved internationally, even though negotiators trying to agree on a comprehensive convention on international terrorism got rather close in the early years of this century. It should also be borne in mind that different aspects of the problem have been defined in the various anti-terrorism conventions and in Security Council (SC) resolutions. For example in "terrorist acts" in SC resolution 1566 (2004). It should also be born in mind that committed individuals have tried their hand at overcoming the stalemate, for example the first UN special rapporteur on promoting and protecting human rights and fundamental freedoms while countering terrorism, Martin Scheinin. ${ }^{9}$

\section{$3 \quad$ Two Sets of Issues}

In looking back, I find it striking how different the issues were at the junction of human rights and counterterrorism in both periods in which I was involved. To some extent that might be the result of working on one side or the other of the divide, but I am convinced that that is only a small part of the difference. I will first enumerate the main issues that I encountered, and towards the end of this article analyse why these sets are so different.

8 As seems the case in the first court sessions in the case of Gökmen T in July and September 2019 .

9 Scheinin made an effort in A/HRC/16/51: "Terrorism means an action or attempted action where: (1) The action: (a) Constituted the intentional taking of hostages; or (b) Is intended to cause death or serious bodily injury to one or more members of the general population or segments of it; or (c) Involved lethal or serious physical violence against one or more members of the general population or segments of it; and (2) The action is done or attempted with the intention of: (a) Provoking a state of terror in the general public or a segment of it; or (b) Compelling a Government or international organization to do or abstain from doing something; and (3) The action corresponds to: (a) The definition of a serious offence in national law, enacted for the purpose of complying with international conventions and protocols relating to terrorism or with resolutions of the Security Council relating to terrorism; or (b) All elements of a serious crime defined by national law." 
The first set is largely defined by the $9 / 11$ attacks in the United States and their aftermath. Some of the events took place in and around the UN in New York (drafting resolutions, talking to Special Rapporteurs) and in Geneva, where the Commission on Human Rights was replaced by the Human Rights Council in 2006. But even more important were frequent bilateral talks with counterparts of a range of states, of course first and foremost the United States. Contacts between the Netherlands and the United States took place at different levels. A central role in the diplomatic efforts by the US State Department in the George W. Bush years was played by its legal counsel John Bellinger.

I will go into both periods, but let me first try to define what in my view the most important problems are. In the first period those were:

- The question that the laws of war, international humanitarian law, are not ideally suited for dealing with the problems of terrorism.

- The understandable, but at the same time often exaggerated US view to see all terrorists or terrorist suspects in the bleakest light, as persons filled with hate, out to kill "us" no matter what, persons who should not return to society.

- These two aspects together lead to the question of what rights the prisoners have and whether terrorists should be heard by civilian ${ }^{10}$ or military courts, with the US choosing the latter and most other states choosing the former.

- In particular there was the question of torture: what are the rules for a state which is a party to the Convention against Torture?

These are all difficult issues. Of course in the later period, 2014-2017 the problems at the junction of countering terrorism and protecting human rights were, in my experience, quite different. In this second period those were:

- The tension between freedom of speech on the one hand and prohibiting hate speech and calls for violence - a problem that has become more complicated by the emergence of social media.

- Everything that has to do with privacy, the surveillance state, modern intrusive ways of following people. How far can one go?

- Many of those who had gone to Syria and Iraq had dual nationality. For Dutch citizens, is taking away their Netherlands nationality an appropriate measure? And is travelling to the area the yardstick?

10 Also civilian courts are confronted with persons that seem a permanent threat to society and "beyond correction". In such cases the conclusion can be a lifelong sentence as was handed down in the case of the murder of Theo van Gogh by Mohammed Bouyeri. In the Dutch system, the alternative is a limited sentence with "tbs" which means that after the end of your sentence you are "at the State's disposal", and a judge, advised by psychologists, has to determine whether you can return to society. 
- Somewhat differently, but still relevant: the implications for persons and organisations that are being listed (nationally and on UN lists) as terrorist, in terms of human rights.

- The space for non-governmental organisations to provide humanitarian assistance in the light of counterterrorism laws.

- There are other issues, like the use of armed drones against terrorists. Although this weapon was used frequently by the Obama administration, the issue did not come up in the meetings I had and fora that I attended. ${ }^{11}$

These are all difficult issues. Of course, there is often a tension between fighting terrorism and respecting human rights. The starting point should be that counterterrorism measures should be compatible with international law, in particular international human rights law, international refugee law, and international humanitarian law. Also, the starting point should be that respect for human rights, fundamental freedoms and the rule of law normally reinforces effective counter-terrorism measures. Human rights violations breed frustration, which can lead to terrorist acts, fortunately only rarely. ${ }^{12}$ These principles are incorporated in the most important policy documents. You find them in the UN Global Counter-Terrorism Strategy (2006) and for example in Security Council resolution 2178 (2014). They are part of the founding principles of the GCTF. It is more a question of how to make these different angles intersect in a just way. How do you do that? One useful contribution is the The Hague Memorandum on Good Practices for the Judiciary in Adjudicating Terrorism Offenses which deals with how to apply the rule of law in terrorism trials and the admissibility of intelligence information. It gives some answers, distinguishing between civil law and common law that might differ where intelligence information cannot be declassified. The Memorandum describes the space within which solutions should be found that appropriately balance the national security concerns of a government and the fair trial rights of the accused. There are many more of such Good Practice documents that can be found on the GCTF website. To my mind, as sets of formally non-binding recommendations, they are useful contributions for looking at terrorism through the right prism, even

11 Some debate has started, see for example the report HRC/34/61 by Ben Emmerson, Scheinin's successor as UN rapporteur. He quotes the UK that it would use targeted killing by a drone "when there is no other option to defend the country from attack and no other means to detain, disrupt or otherwise prevent those plotting acts of terror". So the argument is self defence against an imminent threat. Maybe better than reading articles is watching the film Eye in the Sky (2015) with Helen Mirren.

In April 2019 Bart Schuurman gave an interesting presentation entitled, Barriers to terrorism: a first look at why most extremists never become terrorists. 
though many of the recommendations are not particularly surprising, because they are already practised in the countries with a more progressive judiciary.

\section{$4 \quad$ Issues in the aftermath of $9 / 11$}

Let us go back to the period 2003-2007, to the dark period of the War on Terror. Much of what was wrong with the Bush approach can be summarized in the words CIA prisons and later Guantanamo. It seems a long time ago. In one of our conversations, in March 2007, John Bellinger told me about Zayn Abu Zubaydah, ${ }^{13}$ in the same breath in which he mentioned Khalid Sheikh Mohammed, the brain behind 9/11 and the murderer of Daniel Pearl. In 2002, the CIA had called Abu Zubaydah "the third or fourth man in al-Qaida" and "a senior Usama Bin Laden lieutenant" who had been "involved in every major al-Qaida terrorist operation" and was "a planner of the 11 September hijackings." He "managed a network of [al-Qaeda] training camps," "directed the start-up of a Bin Laden cell in Jordan," and "served as al-Qaeda's coordinator of external contacts, or foreign communications." He was also alleged to be "engaged in ongoing terrorism planning against US interests." These qualifications helped John Yoo $^{14}$ write what has become known as the torture memo to the White House. The memo described torture as the extreme end of using physical and mental pain - say, pain that leads to death or organ failure. That was not allowed (or maybe it was, in extreme circumstances), but below that level, all sorts of pressures were allowed. "And so, for 17 consecutive days in August 2002", in the words of Joseph Margulies, one of Abu Zubaydah lawyers, ${ }^{15}$ he "was tortured. As often as it has been repeated, the litany of this torture is still shocking. His captors hurled him into walls and crammed him into boxes and suspended him from hooks and twisted him into shapes that no human body can occupy. They kept him awake for seven consecutive days and nights. They locked him, for months, in a freezing room. They left him in a pool of his own urine. They strapped his hands, feet, arms, legs, torso, and head tightly to an inclined board, with his head lower than his feet. They covered his face and poured water up his nose and down his throat until he began to breathe the water, so that he choked and gagged as it filled his lungs. His torturers then left

13 Alternate name Zayn al-Abidin Muhammad Husayn, born in Riyadh on 12 March 1971.

14 Readers who have seen Vice, the film about Vice-President Dick Cheney, will remember how Yoo was used by Cheney. Yoo is now a law professor at the University of California, Berkeley.

15 Joseph Margulies, 'The innocence of Abu Zubaydah', The New York Review of Books, 28 September 2018. 
him to strain against the straps as he began to drown. Repeatedly. Until, just when he believed he was about to die, they raised the board long enough for him to vomit the water and retch. Then they lowered the board and did it again. The torturers subjected him to this treatment at least eighty-three times in $\mathrm{Au}-$ gust 2002 alone. On at least one such occasion, they waited too long and Abu Zubaydah nearly died on the board."

Even more shocking is that everything the CIA said in 2002 about Abu Zubaydah was not true and that he still is in Guantanamo, even though he formally has never been accused of any crime. There is a video clip of early 2019 of a talk by another one of his lawyers, ${ }^{16}$ describing Abu Zubaydah as a warm, engaging person. When the lawyer is asked whether Abu Zubaydah is an angry man, he answers: "Yes, angry at me when I don't do my homework well". It reminded me of an extraordinary meeting I had in Riyadh in August 2017 when I visited the Mohammad bin Naif Counselling \& Care Centre and heard about nine Yemeni prisoners who had arrived recently from Guantanamo and who would be released shortly. I asked whether I could speak to them, which was approved. When we had sat down, cross-legged, the psychologist of the Centre explained the approach of the Centre. When he finished I asked a few clarifications, but felt I primarily had to address the ex-detainees, so I asked how do they look back at everything? In anger after one and a half decades? No, one of them said, we want to look to the future, look forward to our family and friends we will see shortly. I realised that such an answer was partially the indoctrination of the re-education centre, but there was also something genuine to it.

All had been in Guantanamo, some had been, like Abu Zubaydah, in CIArun secret prisons before. In the year after $9 / 11$ the US opened a series of prisons in third countries, the so called "black sites", and then denied it - at least till President Bush acknowledged the existence of these sites in a speech on 6 September 2006. Thanks to the Council of Europe rapporteur Dick Marty and others, this network of secret CIA-run prisons, including in Poland and Romania, could be unravelled. ${ }^{17}$ To some extent foreshadowed by the events at the Abu Ghraib prison in Baghdad in 2003, these prisons are a low point for the United States as far as the Rule of Law is concerned. The point of the extraordinary renditions of captives to this prison network was to make sure that the inmates had no rights, other than those given to them by their captors. The United States described the captives as "unlawful enemy combatants". It is

16 Mark Denbeaux, CAGE YouTube, 21 January 2019.

17 First report 12 June 2006, 2nd report 14 February 2007. Poland only acknowledged its role in 2014, but as far as I know the matter was never followed up nationally (see also the report of the Special Rapporteur in A/HRC/34/61). 
true that the Geneva Conventions, making the dichotomy between combatants (GC III on Prisoners of War) and civilians (GC IV on Civilians in times of war), are not ideally suited to deal with the problems of terrorism, but that doesn't mean that these captives fall between the cracks and disappear in a legal black hole. That was probably the biggest policy difference the Netherlands had with the US. We maintained that the Geneva Conventions covered everyone, whether in the one category or the other. "Unlawful enemy combatants" was an effort to wriggle out of that. We had quite a number of discussions in those years with American colleagues, such as John Bellinger, and other State Department colleagues like Mike Kozak and Sandy Hodgkinson. In personal terms these meetings were quite cordial, but the differences of view were clear. I remember Bellinger and also Hodgkinson arguing that there was certainly not a legal black hole. The U.S. had detained a limited number of individuals in secret locations, under supervised conditions and in conformity with U.S. law, Bellinger said.

On Guantanamo we were quite clear, saying that we didn't know the background of many of the Guantanamo detainees, but on the basis of what we did know we had the strong impression that most had simply been in the wrong place at the wrong time. Which is what responsible American officials have since admitted. But Bellinger and others went on describing the procedures in place for making sure that all had actually been engaged in combat: all cases had been reviewed, all could appeal etc. The main take away here, I would say, is that there are reasons for being open about where your prisons are, so that the Red Cross and others can visit. There are reasons for legal procedures to be implemented transparently, otherwise there is no scrutiny, no public or at least expert debate.

We criticized the Americans, but we also tried to be constructive. We supported Professor Nico Schrijver from Leiden University and his colleague, Dr. Larissa van den Herik, when they proposed to bring together a group of European, American and other scholars to discuss these legal issues. Foreign Minister Ben Bot and later Maxime Verhagen supported that with some financial help. That became in April 2007 the Oud-Poelgeest Process, and ended in 2010 with the Leiden Policy Recommendations on Counterterrorism and International Law, ${ }^{18}$ which is still a solid effort to deal with the problems generated by the intersection of counterterrorism and human rights - or international human rights law, international criminal law and international humanitarian law.

18 Larissa van den Herik and Nico Schrijver (eds), Counter-Terrorism Strategies in a Fragmented International Legal Order, Cambridge University Press, 2013. 
We were helped by intensive contact with the United Nations. In the UN Counterterrorism Strategy (2006) there is an emphasis on the protection of human rights while fighting terrorism. In April 2005 the Commission on Human Rights created the Special Rapporteur with that mandate, and I had regular contact with the first rapporteur, Martin Scheinin. ${ }^{19}$

So where are we today with these issues? United States' policy about torture has changed. In 2004 John Yoo's torture memo was replaced by another. ${ }^{20}$ All Bush proclamations on the subject of torture were nullified under Obama on his first days in the office. ${ }^{21}$ The US Supreme Court ruled that prisoners in Guantanamo are entitled minimal protection (Common Article 3 of the Geneva Conventions), contrary to what the Office of the Legal Counsel of the Department of Justice reasoned in 2002, namely that Guantanamo was outside the US legal jurisdiction. Those are all improvements, but Guantanamo is still open, ${ }^{22}$ despite Obama's order to close it, be it with a much reduced population, 40. ${ }^{23}$ When I was Special Counterterrorism Envoy, the topic hardly ever came up in talks. The only time I remember was when the Obama Administration - like the Bush Administration before - came to us with requests to take over some Guantanamo prisoners who could not be returned to their country of origin. When I was Human Rights Ambassador my answer had been: only as part of a comprehensive plan. Under Obama there was a bit more sympathy from the Dutch side and the Cabinet was divided, but the answer was still similar. ${ }^{24}$ Obama's efforts to close Guantanamo were thwarted in December 2011, when legislators in Washington overwhelmingly passed the ambiguously worded National Defense Authorization Act for Fiscal Year 2012, which mandated indefinite military detention of al-Qaeda or Taliban suspects and associated forces without recourse to civilian justice. Obama signed the

19 He was succeeded by a Brit (Ben Emmerson) and the present office holder is a woman from Ireland, Fionnuala Ní Aoláin.

20 John Yoo left the Bush administration in 2003, as did his boss who signed off on his memo, Assistant Attorney General Jay S. Bybee. Bybee was succeeded by Jack Goldsmith, who is the co-founder of the Lawfare blog and who wrote about his experiences in the Bush Administration in The Terror Presidency (2007).

21 Executive Order (EO) 13491 of 22 January 2009.

22 Basically because Congress blocked Obama's efforts. The costs of the prison complex are, according to the New York Times of 18 September 2019, \$13 million per prisoner per year.

23 Of which only nine were ever charged, HRW 27 January 2018. At the end of the Obama Presidency there were 41. Under President Trump one prisoner has been released, in May 2018.

24 Only when the American Government will have taken meaningful steps in the direction of closing the Guantanamo facility, including adjudication of the remaining detainees, the Dutch Government will take this request in consideration (Letter to Parliament, 14 September 2015). 
legislation quietly on New Year's Eve. Moreover President Trump in turn has revoked much of Obama's legacy, in particular the order that Guantanamo be closed. ${ }^{25} \mathrm{He}$ has appointed a veteran from the CIA torture days, Gina Haspel, as head of the CIA and the man who reportedly convinced him that torture was not an effective way to deal with terrorists, Jim Mattis, left as Secretary of Defense in early 2019.

I have three final remarks about the issues at the junction of counterterrorism and human rights during that period:1) I focussed on Guantanamo and the United States, but keeping matters in perspective we sometimes said in those days that, yes, Guantanamo was bad, but probably much worse torture was going on in places we hadn't even heard of. 2) One of the reasons for a focus on the US was because of the way the US dealt with terrorism, many autocrats saw a chance to call all opposition that somehow used violence "terrorists", and acted accordingly. 3) Some of these autocratic regimes refused a dialogue about human rights at all and didn't provide a visa (Zimbabwe, Myanmar). Others did invite me and allowed a discussion about terrorism and human rights, like China (in particular when I visited Xinjiang) and Turkey (when I visited the south-east).

Issues in recent years

While the problems of the past have not all been resolved, the set of human rights issues in relation to fighting terrorism has been quite different in recent years. In my view, the problems of mass surveillance and to a large extent also the problems of the limits of free speech are thoroughly modern. They existed before but both have taken a very different form in the last 15 years. Social media didn't exist when I was Human Rights Ambassador. During that period I got my first blackberry, a revolution!

What is the issue with mass surveillance? That over the past decade or so technological capabilities have improved the capacity of intelligence and law enforcement agencies to carry out targeted surveillance of suspected individuals and organizations, and that the interception of communications provides a valuable source of information by which States can investigate, forestall and

$25 \quad$ EO of 30 January 2018. 
prosecute acts of terrorism. Most States now have the capacity to intercept and monitor calls made on a landline or mobile telephone, enabling an individual's location to be determined, his or her movements to be tracked and his or her text messages to be read and recorded. Targeted surveillance also enables intelligence and law enforcement agencies to monitor the online activity of particular individuals, to penetrate databases and cloud facilities, and to capture the information stored on them. Moreover, an increasing number of States ${ }^{26}$ are making use of malware systems that can be used to infiltrate an individual's computer or smartphone, to override its settings and to monitor its activity. Taken together, these forms of surveillance provide a mosaic of data from multiple sources that can generate valuable intelligence about particular individuals or organization. ${ }^{27}$ So, the questions are: are the right people targeted, that is to say persons against whom solid fact-based suspicions exist? Are legal/ independent reviews the norm? Are non-suspected persons also involved in this datamining? And if they are: is their right to privacy when using electronic communications violated? This sort of questions was hotly debated when in the Netherlands the "Sleepwet", an amendment to the law on the intelligence services, was about to be voted on in Parliament as well as in the run up to a referendum about it. To my mind, in the end it had reasonable guarantees built in.

Professionally I had little to do with this issue during my stint as Special Counterterrorism Envoy, except that I visited the cooperative centre for electronic interception in the war against IS in the Middle East, which worked well in the period that IS fighters were not careful using social media, so that many of them could be located. Later, both for personal communications and for directing terrorist plots, encryption was used, which made acquiring timely information about terrorist attacks much more difficult.

\section{Limits to Free Speech}

Limits to free speech is a topic with an even longer history, but we are no longer dealing with insulting the King or using blasphemous language. The present day problems are very different. What people said privately never counted for the law, but in our age of social media that has changed. Many views are nowadays expressed in written form, say for facebook friends or twitter followers,

26 And not only States - but that falls outside the scope of this article.

27 As we have seen in the Netherlands in the case of the PGP encrypted telephones of the so-called Mocro mafiosi when the encryption was broken in 2016. 
but they can easily leave that limited circle and go viral. So we have a new type of semi-public expressions that travel in ways that the speaker perhaps never intended. This can have consequences that become potentially terrorismrelated if expressions are inciting violence, excessively hateful etc. Where to draw the line? When do such expressions become criminal offenses? Of course that depends on legislation. As is well known, most neo Nazi messages and websites can be found in the United States, because freedom of expression is, generally speaking, broader than in Europe. In Europe, in my experience, no country has wrestled more with these issues than the United Kingdom. An infamous example is Anjem Choudary, leader of the banned al-Muhajiroun, which had inspired more than 100 Britons to join ISIL. He was convicted in 2015 for supporting IS after a cat and mouse play of 20 years, put in prison in 2016, but released in 2018 under a number of conditions. How far are you allowed to go? He praised the 9/11 perpetrators, refused to condemn the July 2005 subway bombings, called for Pope Benedict's execution after his critical remarks about the Prophet Mohamed, and was finally convicted in the UK under the Terrorism Act 2000 for calls to support IS. ${ }^{28}$ Of course, the general point is not about Choudary, but about where are the limits of what you can say, taking into account the podium you have for spreading your messages.

A somewhat related point is what to do with similar extremists who are not nationals of the country where they live. One example I saw close up when I lived in Jordan, was the extradition of Omar Othman alias Abu Qatada from the UK to Jordan ${ }^{29}$ as he, born on the West Bank, had Jordanian nationality. Abu Qatada had been arrested in 2002 for involvement in terrorist organisations. The UK wanted to extradite him; he appealed and the case ended up at the European Court for Human Rights. It first concluded that he should not be extradited, but after extra Jordanian assurances were provided he could be. By then it was 2013. It was an early example of Theresa May's tenacity, who was Home Secretary at the time. Abu Qutada is now a free man in Jordan, but keeps spreading hateful views, in particular about Jews.

Having extremist views, so what? Literally, extremist views are "normal" views, only more extreme, more radical. So, "extremist" as a term is not an ideal descriptor. In the context of the GCTF it was chosen for lack of a better word, when the Countering Violent Extremism (CVE) Working Group was set up. Moreover, curtailing speech, even extremist speech, can be counterproductive. What we mostly, but not exclusively, mean with "extremist" is hateful and threatening, so that it incites violence. It has always been clear that the right to

28 The Guardian, Anjem Choudary convicted of supporting Islamic State, 16 August 2016.

29 Where he had been convicted for terrorist acts before. 
freedom of expression has limits. In the words of ICCPR article 19, these restrictions "shall be such as are provided by law and are necessary a) for respect of the rights or reputation of others; b) for protection of national security or of public order or of public health or morals". Human rights lawyers have made the point that these restrictions should not be misused and should be clearly defined. Fair enough, but when some hate preacher calls to kill the infidel it is a call to violence, which in the Netherlands is clearly punishable. It is encouraging terrorism; it is "violent extremism", even though that is a somewhat strange expression, meaning extremist expressions that call for violence of some sort. In that vein the UN, both the Security Council and the General Assembly, use the formulation: "violent extremism which can be conducive to terrorism". The OSCE speaks of VERTL, Violent Extremism and Radicalization that Lead to Terrorism, keeping the link between extremism and terrorism as tight as possible. In the GCTF we made a special set of recommendations for Preventing and Countering Violent Extremism and Terrorism Online. The starting point for that was not only the need for countering violent extremist expressions online, but also the consideration that the internet is the preferred tool for recruitment and fundraising. In the meantime, plans of action developed in the UN and the GCTF have led to cooperation with the "tech companies". For example the Europol Internet Referral Unit often points out examples of hateful violence inciting posts to these "tech companies" that are going against their own norms. In most cases the company involved, for example facebook, removes the content.

Nationality

One of the measures in the Netherlands Action Plan for an Integral Approach to Jihadism ${ }^{30}$ (August 2014) was to adjust legislation in such a way that Dutch FTFS (those who had left for Syria and Iraq to join terrorist groups) might lose their Dutch nationality. Dutch legislation stipulates that someone who freely joins the armed forces of another state, can lose his Dutch nationality. Wasn't this the same case? In the end the argument that under international law everyone has the right to a nationality, ${ }^{31}$ won the day and the Action Plan, as it was published, acknowledged that the Dutch nationality might only be taken away from those with a dual nationality. The text says that most

\footnotetext{
30 https://www.rijksoverheid.nl/documenten/rapporten/2014/o8/30/actieprogrammaintegrale-aanpak-jihadisme (accessed 28 October 2019).

31 As is laid down in a number of human rights documents including the Universal Declaration (Art 15.1).
} 
identified travellers in fact had dual nationality. In the years after adoption of the proposal the measure had been applied 11 times. $^{32}$

\section{$9 \quad$ Humanitarian Assistance}

Security Council resolutions wisely leave the definition of terrorism and terrorist acts to UN Member States. Early in this century the efforts to agree on a Comprehensive Convention to Combat Terrorism stranded. However, the labelling of certain acts as terrorism in Security Council resolutions ${ }^{33}$ has consequences for Member States. An example is Security Council resolution 1373, which "decides" that ${ }^{34}$ States "shall refrain from any form of support .... to entities or persons involved in terrorist acts"; and also "shall prohibit their nationals or any persons and entities within their territories from making any funds, financial assets ... available for persons who commit ...or participate in the commission of terrorist acts".

This is strong language that all UN Member States are obliged to follow. But how should one interpret these instructions? For example, the Swiss Government supports the Red Cross financially, the Red Cross does humanitarian work in IS territory and helps the wounded irrespective of who the person is. Is that help to a terrorist organization, if the patient is an IS fighter? You could connect this with Security Council resolution 2178 which condemns everyone traveling to IS territory for committing terrorist acts as an FTF. ${ }^{35}$ The claim from critics is that nuance disappears in the legislation of many states, so that the prohibition to travel to IS territory may also apply to the Red Cross worker. Not every claim that someone travels to IS territory as a humanitarian worker should be believed at face value, and sometimes fighters have tried to pose as humanitarian workers. That means that the credibility of the claim that someone is a humanitarian worker needs to be investigated, but the question is

32 NRC, OM: afpakken nationaliteit hindert vervolging Syriëgangers, 3 November 2019. The number was higher, but in a number of cases the decision has been annulled because the persons involved travelled to Syria or Iraq before the law had entered into effect in 2017. An important factor in the debate to apply the measure more often is the argument that is it difficult for the Netherlands to prosecute the persons involved if their nationality has been taken away.

33 S.C. Res. 1373, 1456, 1566, 1624, 2178, 2341, 2354, 2368, 2370, 2395 and 2396.

34 Slightly abbreviated formulations from operative paragraphs 1 and 2 of S.C. Res. 1373.

35 The full quote is: Expressing grave concern over the acute and growing threat posed by foreign terrorist fighters, namely individuals who travel to a State other than their States of residence or nationality for the purpose of the perpetration, planning, or preparation of, or participation in, terrorist acts or the providing or receiving of terrorist training, including in connection with armed conflict, and resolving to address this threat. 
where lies the burden of proof? I am not aware whether Security Council resolution 2178 - which was drafted with GCTF input - has aggravated an existing problem. Moreover, Security Council resolutions 1674 and later 2417 stress, in a somewhat different context, the need for unimpeded access for humanitarian (relief) workers. Nevertheless, depending on national legislation, problems may arise. ${ }^{36}$

Finally, somewhat related to humanitarian assistance, the prohibition of financial assistance to terrorists. The first person convicted in the Netherlands was the brother of a Dutch FTF who had transferred $135^{\circ}$ euro to his brother who had joined Jabhat al-Nusra in Syria and who was convicted of financial assistance to terrorism. ${ }^{37}$ The Security Council resolution applied, the person was listed and I understood the pride of the prosecutor in this case, but at the same time there is a human rights aspect to such a case: "it's family". There is a more general problem with persons on UN or other lists. Some of your rights have been taken away. It used to be a problem that once you were on a list, you couldn't be removed. It was an improvement that, with Dutch support, an Ombudsperson was appointed so that an appeal against listing became possible. Since the creation of the position between $5^{0}$ and 100 persons have been delisted from the UN lists.

For banks, anti-terrorist finance provisions have become much stricter since 2001. Much of that is the consequence of the Patriot Act in the United States and related legislation. This US legislation has filtered through internationally, largely through the Financial Action Task Force or the OECD. In my view FATF originally overreacted in a similar way as the Patriot Act did by declaring that every NGO had a high risk of misuse for terrorist finance. However, that has been nuanced in October 2016. ${ }^{38}$ The other side of the coin is that real time financial information has been crucial in unravelling quite a number of terrorist attacks, for example the ones in Paris in November 2015, as I have seen up close in FATF at the time.

36 In the GCTF the Netherlands has recently taken the lead in stimulating the dialogue between the worlds of counterterrorism and humanitarian assistance. In September 2019 it organised a high level panel discussion between both camps and it will follow up by jointly drafting a set of good practices to regulate the impact of counterterrorism regulations on the work of international NGOS and civil society organisations in order to ensure a more effective and efficient implementation of international humanitarian law and human rights provisions.

37 https://www.recht.nl/rechtspraak/uitspraak/?ecli=ECLI:NL:RBROT:2016:6496.

38 Letter to Parliament of Lilian Ploumen, minister for International Trade and Development Cooperation of 23 October 2017. 
The periods described above in a somewhat impressionistic way are arbitrary and only determined by the fact that in those years my work was related to the juncture of human rights and countering terrorism.

In both periods, the OSCE was an important forum for debate. In my "human rights years" the debates primarily took place in Warsaw during the annual Human Dimension Meeting (HDIM). In my "counterterrorism years" the main venue was Vienna - and one time Washington - where meetings about terrorism, during which human rights issued came up frequently, attracted many diplomats, academics and NGO representatives from both east and west of Vienna.

The main conclusion of what has been described above, is that problems at the junction of countering terrorism and protecting human rights have changed considerably during the last 15 years. Apart from the changes in US legislation and practices mentioned, I see two major factors. 1) The first period described can be called the al-Qaeda period, the second the IS period. These two terrorist organisations differed in how to bring about an Islamic state (although none of this, of course, is primarily about theology). Their methods of recruiting and plotting attacks were also very different. For some years IS felt comfortable in the rather large area in Syria and Iraq it controlled. The occupied area worked as a magnet, leading to the phenomenon of FTFs. 2) The second factor is the development of new technologies that made online communication possible and the use of social media, often encrypted. These new forms of communication enabled the online recruitment of new "soldiers". The same tools of communication were used for directing attacks and for spreading propaganda.

The result was that many recruits from all over the world, often young kids, travelled to the area, because of frustrations in their life or attracted by the tales they were told about the Islamic State. There is always a reason why people do what they do. Radicalisation happens when something crystallizes in someone's mind, based on frustration, a violation of someone's human rights, a personal or political drama. There is always a need to try to understand someone's actions, even though there are barriers and practical limits to this. 